Journal of Advanced Research in Fluid Mechanics and Thermal Sciences

Journal homepage: www.akademiabaru.com/arfmts.html ISSN: 2289-7879

\title{
Wastewater Treatment Process: A Modified Mathematical Model for Oxidation Ponds
}

\author{
Syafiqah Hanis Mohd Fauzi ${ }^{1}$, Norazaliza Mohd Jamil ${ }^{1, *}$ \\ 1 Centre for Mathematical Sciences, Universiti Malaysia Pahang, Lebuhraya Tun Razak, 26300, Gambang, Kuantan, Malaysia
}

\section{ARTICLE INFO}

\section{Article history:}

Received 6 May 2021

Received in revised form 2 July 2021

Accepted 5 July 2021

Available online 13 August 2021

\section{Keywords:}

Oxidation pond; wastewater treatment; sum of squared estimate errors (SSE); MATLAB; mathematical model

\section{ABSTRACT}

Wastewater treatment aims to eliminate as many suspended solids as possible from the remaining water, known as effluent, before it is released into the environment. Pond oxidation methods have been practically proven successful for the wastewater treatment process because of their low construction and maintenance costs. This study aimed to investigate the degradation of wastewater pollutants through an oxidation pond treatment system. The purpose was to observe the relationship between the concentration of bacteria which are phototrophic and coliform, chemical oxygen demand (COD), and dissolved oxygen (DO). In this paper, a modified model consist of a set of an ordinary differential equation (ODE) has been developed by incorporating the Monod Equation. The model was solved numerically using the 4th order Runge Kutta method embedded in the MATLAB software. The sum of squared estimate of errors (SSE) for the modified model was compared with the SSE of the existing model. The results revealed that the modified model demonstrated a lower SSE compared to the existing model. Thus, the modified mathematical model gives better result than the existing model. The model provides an excellent approximation for concentration needed for an oxidized pond to produce good water quality.

\section{Introduction}

Clean water is an essential nutrient for human beings, animals, and plants. The human community, either in everyday lives or manufacturing operations, continues to create more and more waste materials [1]. Wastewater can be categorized into different categories, including agricultural waste, sewage sludge, food waste, household waste, and industrial waste [2]. Around $80 \%$ of industrial effluents are discharged directly into rivers through shallow pits, waste, and drains [3]. The domestic wastewater in Malaysia comes exclusively from organizations, households, and commercial buildings such as schools, hospitals, with the toilet flushing being the most significant [4]. There are two main reasons for the treatment of wastewater; first is to reduce contamination and preserve the environment, and perhaps more importantly, public health protection by safeguarding water sources

\footnotetext{
* Corresponding author.

E-mail address: norazaliza@ump.edu.my
}

https://doi.org/10.37934/arfmts.86.1.7686 
and avoiding the spread of waterborne diseases [5]. Hence, to guarantee that there is no damage to human beings and the environment, wastewater needs to be carefully treated.

Different approaches to the treatment of wastewater have been developed to ensure sufficient water quality. The pond oxidation technique is one of the most frequently used treatment methods for medium-sized populations [6]. Also known as shallow ponds, oxidation ponds are built to treat wastewater through reaction with sunlight, bacteria, and algae [7]. For small communities, ponds have become very common because their low construction and maintenance costs provide a significant financial advantage over other known treatment methods [8]. According to Butler et al., [9], the pond oxidation method is natural since microorganisms such as bacteria and algae are used. A pond oxidation method's primary technique is to degrade pollutants and organic matter under two conditions which are when oxygen is present (aerobic) or absent (anaerobic). Present microorganisms are used at each point to break down the effect of either organic or inorganic compounds and to reduce organic matter into more succinct forms, such as carbon dioxide, water, and cell biomass [10].

There are several forms of mathematical modelling that are frequently used in the process of wastewater treatment as shown in Hamzah et al., [2]. The model developed by Streeter and Phelps is mostly shown as a source, while ODE is the basis for the development of the initial equation for each parameter [11]. An important relationship between the parameters involved in the environment is generated via this model.

Several mathematical models have been proposed for issues in different area. A study was conducted on the Nile Tilapia's (Oreochromis niloticus) bioenergetic fish growth model as cultivated in wastewater oxidation ponds in Thailand, a very successful project area [12]. This study proposed the growth of fish model in ODE to acknowledge the behaviour of fish growth due to several environmental factors such as DO, water temperature, plankton concentration, ammonia, and biochemical oxygen demand (BOD).

Many studies estimating the quality of effluent in rivers and stabilization ponds have been performed. The mathematical model presented by Hussein et al., [13] predicted contaminants levels in a river. The model consisted of coupling diffusion-advection equations by; considering a few nonlinear partial differential equations. The model can be used to predict pollutants and dissolved oxygen according to data given by the Al-Diwaniya environmental directorate.

This paper aims to formulate a modified predictive model for an oxidation pond's wastewater treatment process. This study aims to investigate the dynamics of wastewater pollutants through an oxidation pond treatment system. The purpose is to observe the relationship between the concentration of bacteria which are phototrophic and coliform; with chemical oxygen demand (COD), and dissolved oxygen (DO).

\section{Mathematical Modelling}

In the work of Ockendon et al., [14], a biological-based product, namely mPHO was added into an oxidation pond periodically within three months of the analysis to improve the oxidation pond technique's performance. There were two points in the oxidation pond. The first point was CP1 (influent) where water also known as raw and untreated wastewater flows into the oxidation pond. Application of the $\mathrm{mPHO}$ was done at the CP1 point only. The second point was CP2 (effluent) where the water flows out of the oxidation pond and is called treated wastewater. The MPHO applied to the oxidation pond is highly effective in treating water contamination and harmful biological impurities. It works by removing both solids and pathogens that the oxidation pond cannot remove sufficiently [14]. 
According to Taranaki Regional Council [15], two types of ponds that are commonly used in an oxidation pond system are aerobic and anaerobic ponds. An anaerobic pond is free of or lacks oxygen. The lack of oxygen causes anaerobic bacteria to develop rapidly, in turn, causing damage to the solid content in the effluent. During this process, many nutrients are removed. It is so harmful to aquatic life and the water needs to go through an aerobic pond before it can be released as effluent. According to Shilton and Mara [16], an aerobic pond is a passive or naturally aerated pond. During the aerobic pond treatment, aerobic microorganisms utilize dissolved oxygen; to degrade organic matter and changed them into cell biomass, water, and carbon dioxide. An aerobic pond only depends on oxygen released by phytoplankton throughout the photosynthesis process. Then, the oxygen supplied from the air to the water itself (through aeration) and the movement of oxygen into the surface layers.

The mathematical model for the wastewater treatment process of an oxidation pond was formulated using a set of ordinary differential equations (ODE). In a previous work of Ockendon et al., [14], the equation used is shown below.

$$
\begin{aligned}
& \frac{d P(t)}{d t}=c_{1} P(t)-\left(c_{2} P(t)+c_{3} M(t)\right) P(t)+\frac{c_{4} X(t) P(t)}{X(t)+c_{11}}+\frac{v_{i n} P_{0}(t)}{v_{p}} \\
& \frac{d M(t)}{d t}=c_{5} M(t)-c_{6} M^{2}(t)+\frac{c_{8} X(t) M(t)}{X(t)+c_{12}}+\frac{c_{18} v_{i n} m U(t)}{v_{p}} \\
& \frac{d D(t)}{d t}=-c_{9} D(t)-c_{7} M(t)+\frac{c_{10} X(t) D(t)}{D(t)+c_{14}}+\frac{v_{i n} D_{0}(t)}{v_{p}} \\
& \frac{d X(t)}{d t}=c_{13}\left(X_{a t m}-X(t)\right)-c_{15} X(t) M(t)-c_{16} X(t) P(t)-c_{17} X(t) D(t)+\frac{v_{i n} X_{0}(t)}{v_{p}}
\end{aligned}
$$

where $P(t)$ is the concentration of coliforms in the pond $(m g /$ liter $), M(t)$ is the concentration of phototrophic bacteria (PSB) in the pond where $t$ varies from initial time up to 70 days ( $\mathrm{mg} /$ liter ), $D(t)$ is the concentration of chemical oxygen demand (COD) in the pond ( $m g /$ liter $)$ and $X(t)$ is the concentration of dissolved oxygen (DO) in the pond ( $\mathrm{mg} /$ liter $)$. The description of other parameters is listed in Table 1. The parameter $m, P_{0}, D_{0}, X_{0}, X_{a t m}, v_{i n}, v_{p}$ and $U(t)$ values were obtained from the data in the work of Ockendon et al., [14]. The application of the amount of MPHO to the pond ( $U(t)$ ) follows the JBMI schedule as represented in Figure 1. The MPHO was applied every day except 2 days on the weekend. 
Table 1

Parameters used in the mathematical model

\begin{tabular}{|c|c|c|}
\hline Symbol & Description & Value \\
\hline$m$ & The concentration of PSB in one liter of microbe-based product (mPHO). & $19.1 \mathrm{mg} / \mathrm{liter}$ \\
\hline$P_{0}$ & $\begin{array}{l}\text { The concentration of coliform at CP1 point (influent and the application } \\
\text { of } \mathrm{mPHO} \text { ). }\end{array}$ & $0.32 \mathrm{mg} / \mathrm{liter}$ \\
\hline$D_{0}$ & The concentration of chemical oxygen demand (COD) at influent (CP1). & $160.8 \mathrm{mg} / \mathrm{liter}$ \\
\hline$X_{0}$ & $\begin{array}{l}\text { The concentration of dissolved oxygen (DO) at CP1 point (influent and the } \\
\text { application of } \mathrm{mPHO} \text { ). }\end{array}$ & $2.1 \mathrm{mg} / \mathrm{liter}$ \\
\hline$X_{a t m}$ & The saturated oxygen concentration. & $10 \mathrm{mg} / \mathrm{liter}$ \\
\hline$v_{i n}$ & The average amount of sewage coming in. & 290304 liter/day \\
\hline$v_{p}$ & The volume of the pond. & 2864130 liters \\
\hline$U(t)$ & $\begin{array}{l}\text { The amount of microbe-based product ( } \mathrm{mPHO} \text { ) applied to the pond } \\
\text { according to the JBMI schedule per liter in } 70 \text { days. }\end{array}$ & Refer to Figure 1 \\
\hline$c_{1}-c_{19}$ & The cost functions. & $\begin{array}{l}\text { Refer to Ockendon } \\
\text { et al., [14] }\end{array}$ \\
\hline
\end{tabular}

35

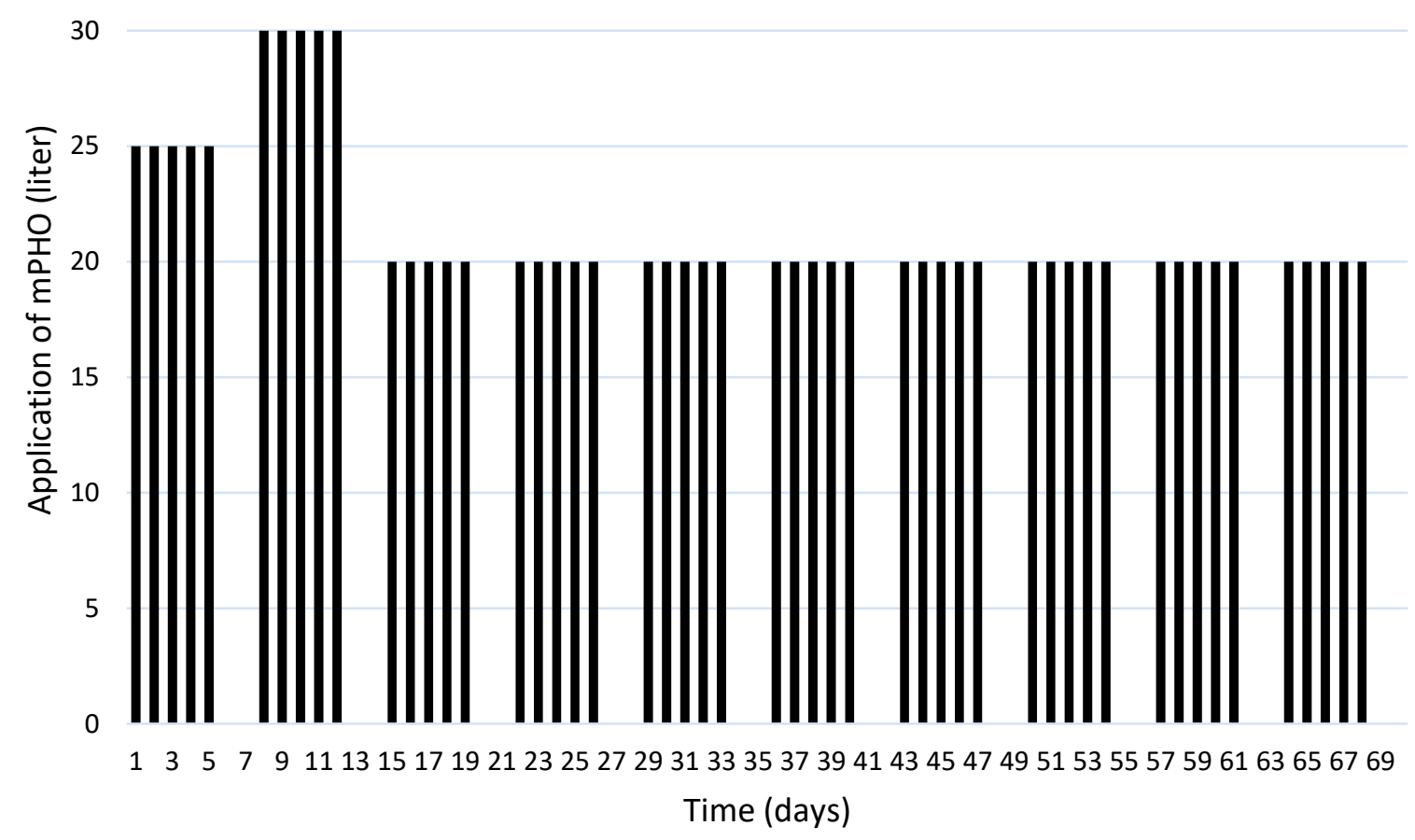

Fig. 1. Amount of microbe-based product (mPHO) applied to the pond according to the JBMI schedule, $U(t)$

In this study, the predictive model aims to observe the relationship between the concentration of bacteria which are phototrophic, $M(t)$ and coliform, $P(t), \mathrm{COD}, D(t)$, and DO, $X(t)$. The model of Ockendon et al., [14] was modified by combining the Monod equation into the Eq. (3) and Eq. (4). The purpose of combining the Monod equation was to determine the specific growth rate of chemical oxygen demand (COD). The modified Eq. (3) and Eq. (4) are written as follows: 


$$
\begin{aligned}
& \frac{d D(t)}{d t}=-c_{9} \frac{w_{1} D(t)}{w_{2}+D(t)}-c_{7} M(t)-c_{10} X(t) \frac{w_{1} D(t)}{c_{14}\left(w_{2}+D(t)\right)}+\frac{v_{i n} D_{0}(t)}{v_{p}} \\
& \frac{d X(t)}{d t}=c_{13}\left(X_{a t m}-X(t)\right)-c_{15} X(t) M(t)-c_{16} X(t) P(t)-c_{17} X(t) \frac{w_{1} D(t)}{w_{2}+D(t)}+\frac{v_{i n} X_{0}(t)}{v_{p}}
\end{aligned}
$$

where $w_{1}$ is the maximum growth rate coefficient that occurs at $0.5 \mu_{\max }\left(d a y^{-1}\right)$, and $w_{2}$ is the halfsaturation coefficient ( $m g /$ liter ) [17].

The Monod equation is a fixed relationship between growth rate and concentration of bulk substrates [18]. The Monod equation defines the relationship between a specific growth of microbial growth regarding the COD concentration, $D(t)$ of the limiting nutrient (substrate) in an oxidation pond [19]. The half-saturation coefficient, $w_{2}$ relates the influence of COD of the wastewater to the growth rate of bacteria. If the COD concentration levels are high, it means a higher volume of organic oxidizable content is in the wastewater, which will decrease dissolved oxygen (DO) concentration. If DO is decreased, it can lead to anaerobic conditions damaging to higher types of aquatic life [20]. Thus, it is crucial to balance or control the COD concentration, which leads this study to use the Monod equation to focus more on COD.

The new model is solved numerically using the $4^{\text {th }}$ order Runge Kutta method embedded in the MATLAB software, and it contains Eq. (1), Eq. (2), Eq. (5), and Eq. (6). The parameter fitting technique which is known as the Nelder-Mead simplex algorithm was used to obtain all the parameter value ( $c_{1}$ until $c_{18}, w_{1}$ and $\left.w_{2}\right)$.

The predictive model was compared with experimental data by Ockendon et al., [14], and the sum of the squared estimate of error (SSE) was computed to fit the model to the data. The SSE equation is shown as follows:

$$
S S E=\sum_{i=1}^{N}\left(x \exp _{i}-x c a l_{i}\right)^{2}
$$

where $x \exp _{i}$ is the experimental value of the dependent variable of the $i$ th experiment, $x c a l_{i}$ is the calculated value from the model for the $i$ th experiment and $N$ is the total number of experiments.

\section{Results and Discussion}

The quality of wastewater treatment is determined by the concentration of bacteria, phototrophic and coliform, chemical oxygen demand (COD), and dissolved oxygen (DO). The proposed model determines the specific growth rate of bacteria and the concentration of COD. The chemical oxygen demand (COD) is a measurement of the oxygen needed to oxidize the organic matter in water that is soluble and particulate. Thus, it was observed by combining the Monod equation as stated above.

The proposed model parameter was estimated using a parameter fitting obtained using the Nelder-Mead simplex algorithm that has been calculated. These procedures were iteratively performed until some appropriate values for the parameters were achieved. After conducting the procedure, the value of the parameters was obtained, as shown in Table 2. 
Table 2

Parameter's value of the proposed model

\begin{tabular}{|c|c|}
\hline Parameter & Value \\
\hline$c_{1}$ & $0.000164938309339 \times 10^{2}$ \\
\hline$c_{2}$ & $0.003705410106377 \times 10^{2}$ \\
\hline$c_{3}$ & $0.000006772155312 \times 10^{2}$ \\
\hline$c_{4}$ & $0.000005832028579 \times 10^{2}$ \\
\hline$c_{5}$ & $0.000000000835499 \times 10^{2}$ \\
\hline$c_{6}$ & $2.225057806655565 \times 10^{2}$ \\
\hline$c_{7}$ & $0.000159103253785 \times 10^{2}$ \\
\hline$c_{8}$ & $0.000000000188800 \times 10^{2}$ \\
\hline$c_{9}$ & $0.000010005879956 \times 10^{2}$ \\
\hline$c_{10}$ & $0.001457335475730 \times 10^{2}$ \\
\hline$c_{11}$ & $0.000417179668896 \times 10^{2}$ \\
\hline$c_{12}$ & $0.008965356210846 \times 10^{2}$ \\
\hline$c_{13}$ & $0.000000279109030 \times 10^{2}$ \\
\hline$c_{14}$ & $0.001178471721421 \times 10^{2}$ \\
\hline$c_{15}$ & $0.005168113067381 \times 10^{2}$ \\
\hline$c_{16}$ & $0.002014873870683 \times 10^{2}$ \\
\hline$c_{17}$ & $0.000003497969054 \times 10^{2}$ \\
\hline$c_{18}$ & $0.000000000019313 \times 10^{2}$ \\
\hline$w_{1}$ & $0.033793939759916 \times 10^{2}$ \\
\hline$w_{2}$ & $0.000208353658884 \times 10^{2}$ \\
\hline
\end{tabular}

The predictive modified model was solved using all the parameters above. Then, the models were compared to the experimental data reported in the work of Ockendon et al., [14]. The predictive modified model was solved numerically using the parameters in Table 2 to obtain the results represented in Figure 2 to Figure 5. The growth of the concentration of bacteria, phototrophic and coliform, chemical oxygen demand (COD), and dissolved oxygen (DO) rates were observed from Day 1 until Day 70.

Figure 2 is the simulation result of the microbe's coliform concentration and experimental data obtained from the pond at point CP2 [14]. The figure shows that the concentration of coliform as shown by the model kept increasing starting from Day 1 , and the concentration was maintained until the end of the period. Under certain conditions, coliform bacteria in a pollutant pond could fail to survive. In contrast, other bacteria or viruses continue to sustain health risks in the absence of indicator species as stated by McFeters and Stuart [21]. Figure 3 depicts the simulation results of PSB compared to the experimental data. Phototrophic bacteria (PSB) in $\mathrm{mPHO}$ are beneficial microorganism products that improve water quality. As shown in Figure 3 , as represented by experimental data, the PSB concentration rate increased sharply from Day 42 until 49 and then decreased sharply until the end of the treatment process. That is because there is a specific rate where the soluble substrate will be exhausted by the bacteria. The utilization rate became high at an increased substrate concentration and will be virtually even to the soluble substrate utilization maximum rate [22]. As shown Figure 2 and Figure 3 note the same day for the concentration 
increment event. The simulated results in Figure 3 as denoted by the blue curve note the increasing concentration until the end of the process. The reasons are that PSB in mPHO acts as a cleansing agent of the wastewater, thus it has the capability of reducing the concentration of pathogenic bacteria (E. Coli and Coliform), biochemical oxygen demand (BOD), COD and other pollutants as the PSB and DO concentration increase [23]. In a previous work by Talaiekhozani and Rezania [24], they summed up their study by stating that PSB can eliminate contaminants by briefly discussing three significant aspects: light, temperature, and nutrients and their effect on the rate of growth of PSB.

Figure 4 is the simulation results of the chemical oxygen demand (COD) concentration and experimental data against time. As shown in Figure 4, the COD concentration's simulation curve kept increasing as the number of days increased. However, the concentration of COD always lower than the experimental data at the CP2 point. The experimental data also kept rising until the end of the treatment period. Despite the increment in Figure 4, the concentration rate of COD decreased more when comparing the concentration rate at the CP1 point (influent and the application of $\mathrm{mPHO}$ ) as reported by Ockendon et al., [14] and the CP2 point (effluent) as shown in Figure 4. Therefore, the higher the COD, the higher the level of pollutants in the water [25]. Hence, the simulated results predict that lower COD concentrations are suitable for better water quality. COD is known as one of the significant quality assurances parameters of effluent in wastewater treatment [26]. COD is a measurement that determines the amount of oxygen needed to oxidize soluble and particulate organic matter in water [27]. Meanwhile, dissolved Oxygen (DO) is a measurement used to determine the amount of oxygen dissolved in water [3]. That means that COD and DO are closely related to each other. The mathematical model resulted in the further removal of COD as well as an increase of DO. Next, Figure 5 describes the results on dissolved oxygen (DO) through time (days). The figure depicted a regression curve that shows the rise of DO concentration until Day 10 and its subsequent decrease until the end of the period. Although it seemed to decrease, it showed good increment compared to the amount of DO in CP1 point as stated by Ockendon et al., [14]. As the concentration of oxygen intake by aerobic decomposers exceeded the reaeration rate, the concentration of DO started to decrease and certain species were removed. If DO degradation continues, the aerobic decomposers continue to operate, and the anaerobic species populate the water [28]. The DO was reduced because it went through variations in species composition. After all, oxygen concentration is influenced by chemical reactions.

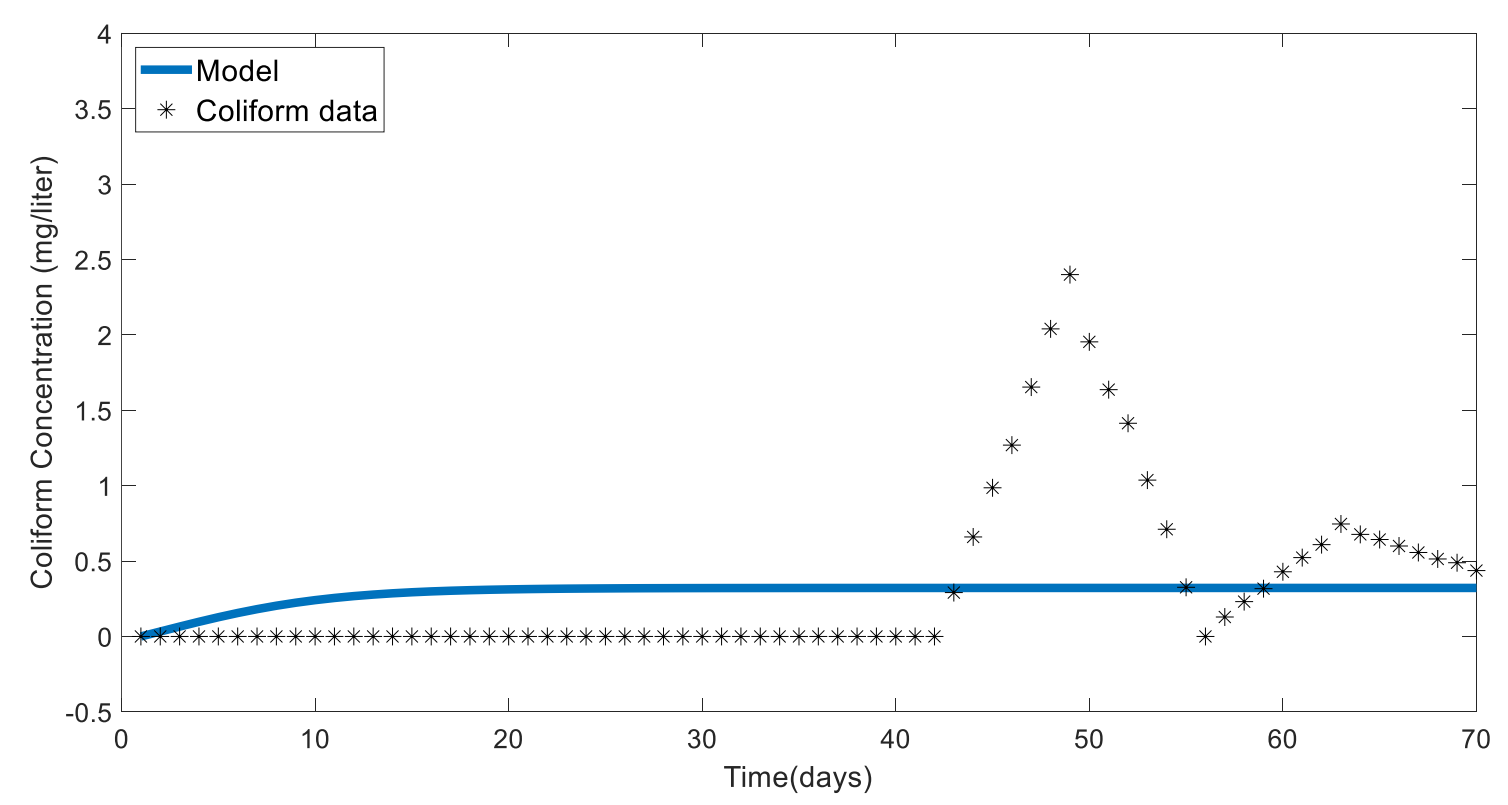

Fig. 2. Simulation results of microbes' coliform concentration and experimental data against time 


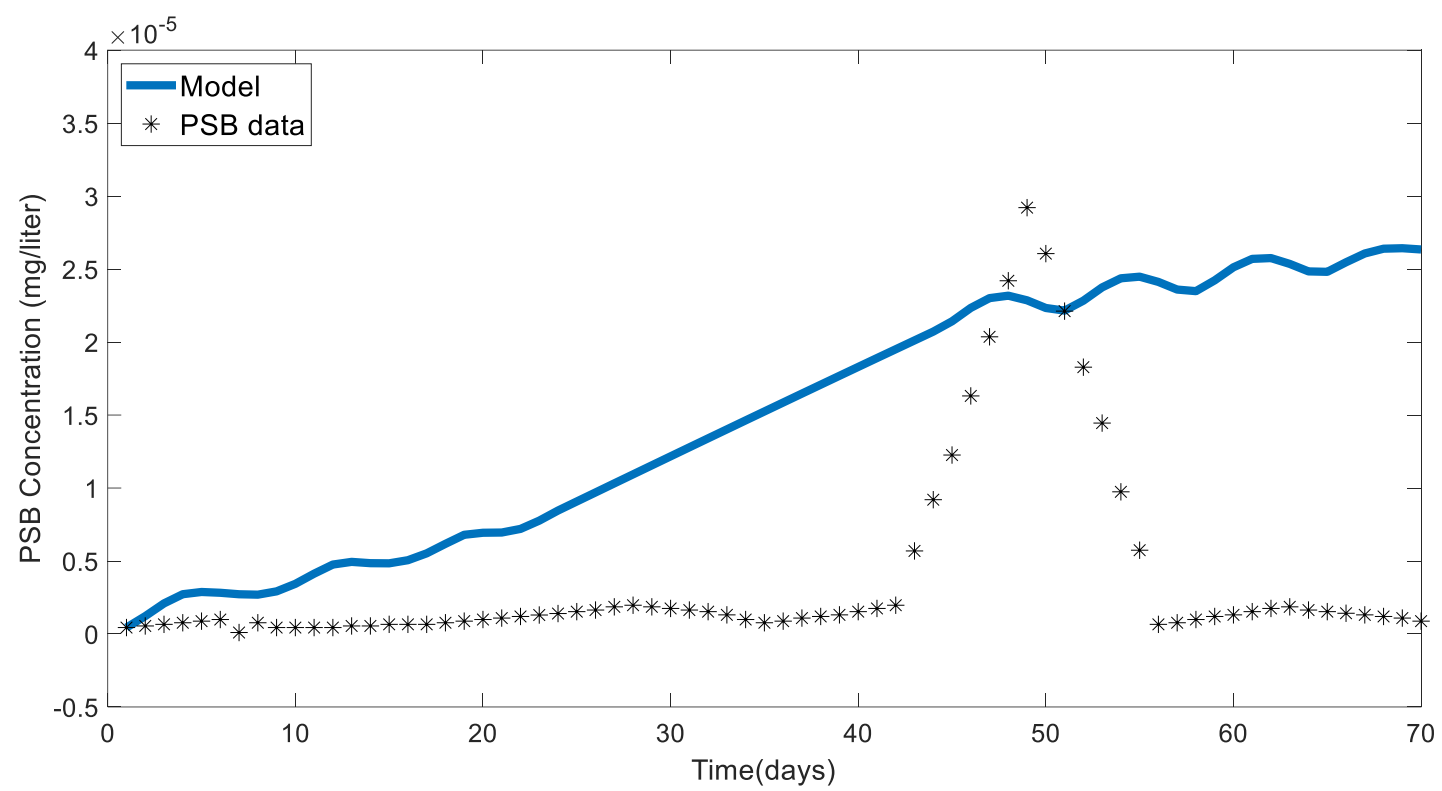

Fig. 3. Simulation result of PSB (Phototrophic Bacteria) concentration and experimental data against time

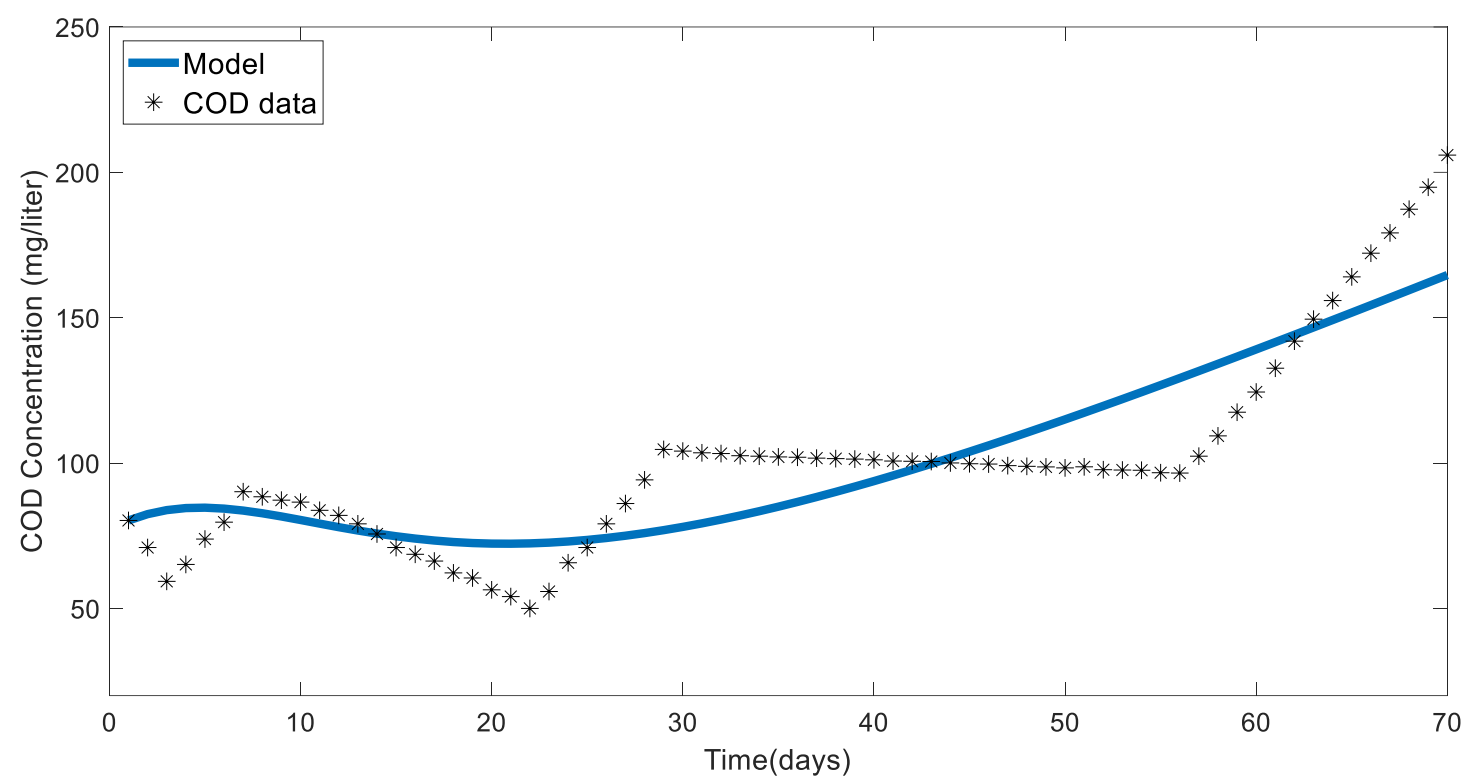

Fig. 4. Simulation result of chemical oxygen demand (COD) concentration and experimental data against time 


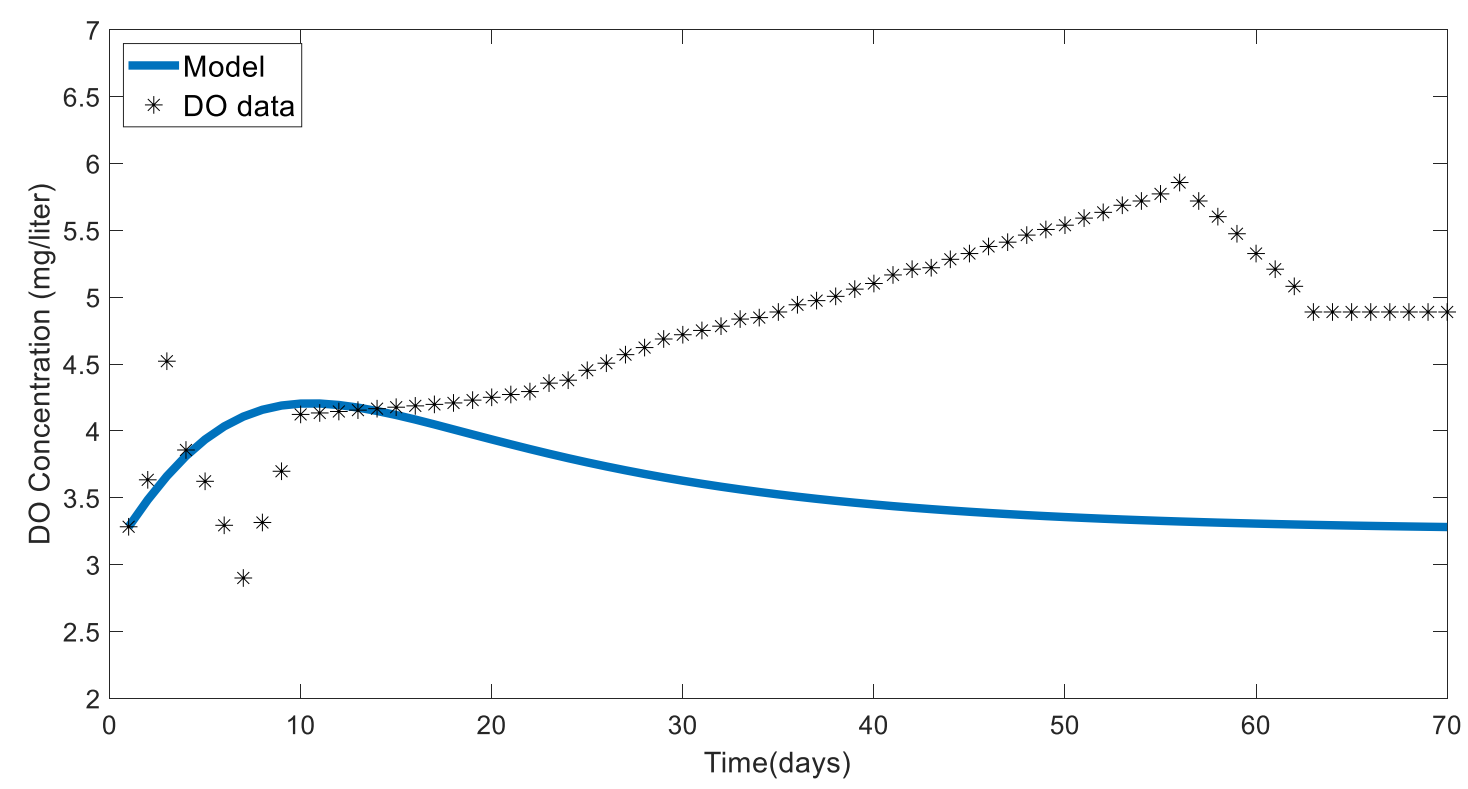

Fig. 5. Simulation result of dissolved oxygen (DO) concentration and experimental data against time

Also, this study makes a comparison between the two approaches (existing model by Ockendon et al., [14] and modified model) based on the SSE value that has been obtained. There have been relatively large variations between the two models, indicating that the proposed model has been substantially improved.

Table 3 represents the SSE (sum of the squared estimate of errors) of the existing model by Ockendon et al., [14] and the modified predictive model. Table 3 indicates that the SSE value of the modified predictive model approximates the data along the regression line more precisely compared to the current model. That is because the modified predictive model showed a lower SSE value compared to the existing model. Using Eq. (3) and Eq. (4) that had been modified into Eq. (5) and Eq. (6) by combining the Monod equation, this study has proven to produce better results than the existing model.

\section{Table 3}

Comparison of SSE values of existing model against modified predictive model

\begin{tabular}{ll}
\hline SSE value of the existing model & SSE value of the modified predictive model \\
\hline $3.074069576875604 \times 10^{4}$ & $1.979820636734577 \times 10^{4}$ \\
\hline
\end{tabular}

\section{Conclusion}

In this study, a modified predictive model for an oxidation pond was developed for the wastewater treatment process. Also, this study obtained a set of optimum parameters for developing the modified predictive mathematical model using actual data. The modified predictive model showed better results compared to the existing model as proven by comparisons of the SSE value. Thus, the set of ordinary differential equations (ODE) which incorporated the Monod equation has been proven to be successful. The model can be used to determine the dynamic concentration of bacteria, coliform and PSB, COD, and DO, and demonstrate the efficiency of $\mathrm{mPHO}$ in enhancing oxidation ponds' water quality. The $\mathrm{CP} 2$ points showed that $\mathrm{mPHO}$ has a strong effect on reducing $\mathrm{BOD}, \mathrm{COD}$, and pollutant concentration, while coliform bacteria increase PSB and DO concentrations. The water quality parameter was also calculated. The mathematical model proposed enables the 
predictions of amount concentration using Monod equation, therefore presenting a depiction of removal pollutants' dynamics within the treatment process. It is necessary to use the Monod equation because it relates microbial pathogens' growth to the nutrient present in the pond. However, the right amount of $\mathrm{mPHO}$ must be defined to ensure an appropriate dose is added, its quality is preserved, and its overused is prevented.

\section{Acknowledgement}

This research was funded by a grant from Universiti Malaysia Pahang, Internal Grant RDU 210329. (Ref: UMP.05/26.10/03/RDU210329).

\section{References}

[1] Hamzah, Amir SA, Ali HM Murid, Zainal A. Aziz, Akbar Banitalebi, Hazzarita Rahman, and Norazelah Hamdon. "Modeling of microbial approach in wastewater treatment process: A case study of mPHO in Taman Timor oxidation pond, Johor, Malaysia." In AIP Conference Proceedings, vol. 1750, no. 1, p. 030023. AIP Publishing LLC, 2016. https://doi.org/10.1063/1.4954559

[2] Hamzah, Amir SA, Akbar Banitalebi, Ali HM Murid, Zainal A. Aziz, Hasniza Ramli, Hazzarita Rahman, and Norazelah Hamdon. "A Mathematical Model for Wastewater Treatment Process of an Oxidation Pond." Jurnal Teknologi 78, no. 3-2 (2016). https://doi.org/10.11113/it.v78.7815

[3] Latiffi, Nur Atikah Ahmad, Radin Maya Saphira Radin Mohamed, Vicky Airama Shanmugan, Najeeha Mohd Apandi, Ramlah Mohd Tajuddin, and Amir Hashim Mohd Kassim. "Characteristics of Water Quality from Meat Processing Wastewater." Journal of Advanced Research in Applied Sciences and Engineering Technology 17, no. 1 (2019): 7884.

[4] Katayon, S., MJ Megat Mohd Noor, W. Kien Tat, G. Abdul Halim, A. M. Thamer, and Y. Badronisa. "Effect of natural coagulant application on microfiltration performance in treatment of secondary oxidation pond effluent." Desalination 204, no. 1-3 (2007): 204-212. https://doi.org/10.1016/j.desal.2006.03.541

[5] Gray, Nick Frederick. Biology of wastewater treatment. Vol. 4. World Scientific, 2004. https://doi.org/10.1142/p266

[6] Abdel-Shafy, Hussein I., and Mohammed AM Salem. "Efficiency of oxidation ponds for wastewater treatment in Egypt." In Wastewater Reuse-Risk Assessment, Decision-Making and Environmental Security, pp. 175-184. Springer, Dordrecht, 2007. https://doi.org/10.1007/978-1-4020-6027-4 18

[7] Muhammad, Nurul Nadiah, Dennis Ling Chuan Ching, and Amir Syafiq Syamin Syah Amir Hamzah. "Mathematical Modelling of Wastewater Treatment in Oxidation Pond." Journal of Computational and Theoretical Nanoscience 16, no. 11 (2019): 4455-4460. https://doi.org/10.1166/ictn.2019.8618

[8] Horan, Nigel J. Biological wastewater treatment systems: theory and operation. John Wiley \& Sons Ltd., 1989.

[9] Butler, Erick, Yung-Tse Hung, Mohammed Suleiman Al Ahmad, Ruth Yu-Li Yeh, Robert Lian-Huey Liu, and Yen-Pei Fu. "Oxidation pond for municipal wastewater treatment." Applied Water Science 7, no. 1 (2017): 31-51. https://doi.org/10.1007/s13201-015-0285-z

[10] Hamzah, Amir Syafiq Syamin Syah, and Ali Hassan Mohamed Murid. "Nonlinear Partial Dierential Equations Model Related to Oxidation Pond Treatment System: A Case Study of mPHO at Taman Timor Oxidation Pond, Johor Bahru." MATEMATIKA: Malaysian Journal of Industrial and Applied Mathematics 34, no. 2 (2018): $293-311$. https://doi.org/10.11113/matematika.v34.n2.1038

[11] Beck, M. Bruce, and Peter C. Young. "A dynamic model for DO-BOD relationships in a non-tidal stream." Water Research 9, no. 9 (1975): 769-776. https://doi.org/10.1016/0043-1354(75)90028-7

[12] Dampin, Narouchit, Wit Tarnchalanukit, Kasem Chunkao, and Montri Maleewong. "Fish growth model for Nile tilapia (Oreochromis niloticus) in wastewater oxidation pond, Thailand." Procedia Environmental Sciences 13 (2012): 513-524. https://doi.org/10.1016/i.proenv.2012.01.042

[13] Hussain, Saleem Azara, Waggas Galib Atshan, and Zainab Mohammed Najam. "Mathematical Model for the Concentration of Pollution and Dissolved Oxygen in the Diwaniya River (Iraq)." American Journal of Scientific Research 78 (2012): 33-37.

[14] Ockendon, John R., Graeme Wake, Kok Lay Teo, Ryan Loxtan, Adérito Araújo, Basuki Widodo, Ali Hassan Mohamed Murid et al. "Mathematical Modeling and Optimization for Biological-based Treatment of Taman Timor Oxidation Pond, Johor." Malaysian 2nd Mathematics in Industry Study Group (MISG 2014) (2014): 1-37.

[15] Council, Taranaki Regional. New Plymouth District Council Inglewood Oxidation Ponds System Monitoring Programme Annual Report 2014-2015. TRC Technical Report 2015-18, 2015. 
[16] Shilton, A. N., and D. D. Mara. "CFD (computational fluid dynamics) modelling of baffles for optimizing tropical waste stabilization pond systems." Water Science and Technology 51, no. 12 (2005): 103-106. https://doi.org/10.2166/wst.2005.0438

[17] Samer, Mohamed. "Biological and Chemical Wastewater Treatment Processes." In Wastewater Treatment Engineering. IntechOpen, 2015. https://doi.org/10.5772/61250

[18] Moo-Young, Murray. Comprehensive biotechnology. Elsevier, 2019.

[19] Konak, A. R. "Derivation of a generalised Monod equation and its application." Journal of Applied Chemistry and Biotechnology 24, no. 8 (1974): 453-455. https://doi.org/10.1002/jctb.5020240805

[20] Kayombo, S., T. S. A. Mbwette, Jamidu HY Katima, and S. E. Jorgensen. "Effects of substrate concentrations on the growth of heterotrophic bacteria and algae in secondary facultative ponds." Water Research 37, no. 12 (2003): 2937-2943. https://doi.org/10.1016/S0043-1354(03)00014-9

[21] McFeters, Gordon A., and David G. Stuart. "Survival of coliform bacteria in natural waters: field and laboratory studies with membrane-filter chambers." Applied Microbiology 24, no. 5 (1972): 805-811. https://doi.org/10.1128/AEM.24.5.805-811.1972

[22] Howell, J. A., and B. Atkinson. "Influence of oxygen and substrate concentrations on the ideal film thickness and the maximum overall substrate uptake rate in microbial film fermenters." Biotechnology and Bioengineering 18, no. 1 (1976): 15-35. https://doi.org/10.1002/bit.260180103

[23] Hamzah, Amir Syafiq Syamin Syah Amir. "Mathematical modelling of biological wastewater treatment of oxidation pond and constructed wetland systems." PhD diss., Faculty of Science, Universiti Teknologi Malaysia, 2017.

[24] Talaiekhozani, Amirreza, and Shahabaldin Rezania. "Application of photosynthetic bacteria for removal of heavy metals, macro-pollutants and dye from wastewater: A review." Journal of Water Process Engineering 19 (2017): 312-321. https://doi.org/10.1016/i.jwpe.2017.09.004

[25] Cooper, C. M. "Biological effects of agriculturally derived surface water pollutants on aquatic systems-a review." Journal of Environmental Quality $22, \quad$ no. $3 \quad$ (1993): $402-408$. https://doi.org/10.2134/jeq1993.00472425002200030003x

[26] Alam, Tasnim. "Estimation of Chemical Oxygen Demand in WasteWater using UV-VIS Spectroscopy." PhD diss., Applied Sciences: School of Mechatronic Systems Engineering, 2015. https://doi.org/10.1109/ICSENS.2015.7370460

[27] Li, Daoliang, and Shuangyin Liu. Water quality monitoring and management: Basis, technology and case studies. Academic Press, 2018. https://doi.org/10.1016/B978-0-12-811330-1.00001-6

[28] Płuciennik-Koropczuk, Ewelina, and Sylwia Myszograj. "New approach in COD fractionation methods." Water 11, no. 7 (2019): 1484. https://doi.org/10.3390/w11071484 